\title{
Psychoactive Substance Use Among Nigerian Students; Patterns and Sociodemographic Correlates
}

\section{Chukwujekwu Chidozie Donald}

Department of Neuropsychiatry, Faculty of Clinical Sciences, University of Port Harcourt, Port Harcourt, Nigeria

\section{Email address:}

chidozie.chukwujekwu@uniport.edu.ng

\section{To cite this article:}

Chukwujekwu Chidozie Donald. Psychoactive Substance Use Among Nigerian Students; Patterns and Sociodemographic Correlates. American Journal of Psychiatry and Neuroscience. Vol. 5, No. 2, 2017, pp. 22-25. doi: 10.11648/j.ajpn.20170502.13

Received: April 12, 2017; Accepted: April 18, 2017; Published: April 24, 2017

\begin{abstract}
The increase in use and misuse of psychoactive substances is a global challenge of grave public health concern. This study aims to ascertain the patterns and socio-demographic correlates of psychoactive substances among undergraduates in a Nigerian University. Two hundred and ninety three subjects participated in the study. Questionnaires on risk factors and variation of psychoactive substances abused as well as on socio-demographic variables were administered to each participant. The prevalence of psychoactive substance use was $65.5 \%$. the odds for use of the drugs was highest with alcohol $178(60.8 \%)$ and least for inhalational solvents $75(25.6 \%)$. There was significant association between gender and the use of: Cannabis $\mathrm{X}^{2}=$ 7.846, $\mathrm{df}=1, \mathrm{p}<0.05$, Cocaine $\mathrm{X}^{2}=36.602, \mathrm{df}=1, \mathrm{p}<0.05$, Other opioids $\mathrm{X}^{2}=29.847, \mathrm{df}=1, \mathrm{p}<0.05$, Sleeping pills $\mathrm{X}^{2}=9.862$, $\mathrm{df}=2, \mathrm{p}<0.05$. Nicotine $\mathrm{X}^{2}=17.264, \mathrm{df}=1, \mathrm{p}<0.05$, Inhalational solvents $\mathrm{X}^{2}=6.598, \mathrm{df}=1, \mathrm{p}<0.05$. Similarly, there was significant association between academic class and:- Cannabis $\mathrm{X}^{2}=14.916, \mathrm{df}=5, \mathrm{p}<0.05$, Heroine $\mathrm{X}^{2}=12.272, \mathrm{df}=5$, $\mathrm{p}<0.05$, Codeine $X^{2}=9.577, \mathrm{df}=1, \mathrm{p}<0.05$, Other Opioids $X^{2}=15.962, \mathrm{df}=5, \mathrm{p}<0.05$, Nicotine $X^{2}=15.496, \mathrm{df}=5, \mathrm{p}<0.05$, Caffeine $X^{2}=13.428, d f=5, p<0.05$, Inhalational solvents $X^{2}=21.505, d f=5, p<0.05$. Also there was significant association between family history of use of psychoactive substances and use of Opioids $X^{2}=8.157, d f=1, p<0.05$ The propensity of use of psychoactive substance has become a global emergency that requires desperate measures to curtail. This study is an effort to further emphasize this urgency.
\end{abstract}

Keywords: Psychoactive, Substances, Alcohol, Prevalence, Drugs, Associated, Significant

\section{Introduction}

The abuse of several classes of psychoactive substances has been remarkably in the increased globally in recent times. In a bid to stem the tide of this multidimensional malady, many countries have resorted to prescribing capital punishment for convicted drug traffickers.

Psychoactive substances are drugs that alter both internally perceived mental states such as mood and externally observable activities such as behaviour, and comprise alcohol, cocaine, opium, cannabinoids, amphetamines, sedative and hypnotics, anxyolytics and other stimulants such as caffeine, hallucinogens, nicotine, volatile solvents and phencyclidine $[1,2,3]$.

Alcohol and tobacco use account for $5.4 \%$ and $3.7 \%$ of total burden of disease [4]. This underscores the seriousness of the burning global issue of drug abuse. The availability of a bewildering array of illicit drugs used for recreational purposes among other things has led to the escalation in the use and misuse of psychoactive substances in our environment [1]. The rapid economic, social and cultural transitions that most countries in substances Africa are now undergoing have provided a favourable climate for increased maladaptive use of psychoactive substances [5]. The consequence of drug abuse on the individual, family and society are myriad and have psychosocial, physical and economic dimensions. Not only is it a significant cause of mortality, drug abuse robs the youth of initiative, it hinders the fulfillment of one's life goals, disrupts the family, because it is the substrate upon which exacerbation ofsocial vices, sexual and violent crimes of monumental preparation thrive $[1,6,7]$.

Even though a number of studies have been carried at in Nigerian on drug abuse, most of the studies are been carried out in other parts of Nigeria with paucity of information in the Niger Delta region of Nigeria [8, 9, 10].

The oil rich Niger Delta region of Nigeria has been 
embroiled in crisis for more than 2 decades now. The crisis has been exacerbated by emergent issues of distortion to Nigeria federalism in respect of resource control, environmental degradation and marginalization of the host communities where oil exploration is carried out. This has led to the emergence of aggrieved militant gangs who have been wrecking violence, with associated increased crime rate in the region. At the root of most of this acts is substance abuse $[11,12]$.

The aim of this study therefore is to explore psychoactive drug consumption among undergraduate students in a university in the Niger Delta region of Nigeria and identify the patterns of use and risk factors for the abuse. This will enable the development of adequate interventions that will lead to stemming the tide of this dangerous monumental challenge.

\section{Methodology}

This cross sectional study was conducted among undergraduate students at Madonna University Elele in Rivers State. The school has a student population of 5235 students. The study took place within a 4 month period (February -May 2015)

\subsection{Instruments: The Instruments Used in This Research Include}

(1) A questionnaire on risk factors and varieties of psychoactive substances abused; designed by the authors. It consist of 2 sections: a section with ten questions aimed at ascertaining the variety of psychoactive substance abused and another section with eight question meant to elicit the risk factors for the use of these substances. Subjects were meant to answer either "yes" or "no" to the questions. Before the commencement of the study, a pilot study was carried at using the questionnaire which demonstrated a discriminant validity of $89 \%$.

(2) A questionnaire on socio-demographic variables.

\subsection{Procedure}

Via random sampling 293 students who consented to the study were enlisted. Before the commencement of the study a verbal consent was obtained from the respondents and they were assured of confidentiality as their names were not included in the questionnaire. The students selected, completed the questionnaire during class hours after explanations on what to do.

\subsection{Analysis}

The data was analyzed using the Statistical Package of the Social Sciences (SPSS) version 15. Statistical methods applied comprise: frequency counts and tables, tests for association (chi-square test for categorical variables and student's t- test for continuous variables).

It is important to note that what is presented in this paper "Psychoactive Substance use among Nigerian Students; Patterns and Socio-demographic Correlates" is part of that larger study.

\section{Results}

The two hundred and ninety three subjects who participated in the study were analyzed.

Mean age was $23.89 \pm 3.148$ years and they were mainly between 21-30yrs. Respondents were mainly males 166 $(56.7 \%)$, in the $4^{\text {th }}$ year class $85(29.0 \%)$ and had no family history of use of psychoactive substances $239(81.6 \%)$. See table 1.

The odds for the use of psychoactive substances was highest with alcohol $178(60.8 \%)$ followed by caffeine $168(57.3 \%)$, codeine 141 (48.1\%), sleeping pills $129(44.0 \%)$ and nicotine $128(43.7 \%)$. It was least with inhalational agents $75(25.6 \%)$.

The odds for use of all the psychoactive substances were higher among the male subjects compared with their female counter parts. See table 3 .

Table 4 shows the association between the use of psychoactive substances and socio-demographic variables.

There is significant association between cannabis use and gender. $\mathrm{X}^{2}=7.846, \mathrm{df}=1, \mathrm{p}<0.05$ as well as with academic class, $X^{2}=14.916, \mathrm{df}=5, \mathrm{p}<0.005$.

Similarly there is significant association between the use of cocaine and gender $\mathrm{X}^{2}=36.6022, \mathrm{df}=1, \mathrm{p}<0.05$, the use of heroine and academic class $X^{2}=12.272, d f=5 p<0.05$, and the use of codeine and academic class $X^{2}=9.577, \mathrm{df}=1 \mathrm{p}<0.05$.

Use of other opioids was significantly associated with gender $\quad\left(X^{2}=29.847, \quad d f=1, \quad p<0.05\right), \quad$ academic class $\left(X^{2}=15.962, d f=5, p<0.05\right)$ and family history of use of opioids $\left(\mathrm{X}^{2}=8.157, \mathrm{df}=1, \mathrm{p}<0.05\right)$. Use of sleeping pills was significantly associated with age $\left(X^{2}=65.875, \quad d f=36\right.$, $\mathrm{p}<0.05)$, and gender $\left(X^{2}=9.862, \mathrm{df}=2, \mathrm{p}<0.05\right)$. The use of nicotine was significantly associated with gender $\left(X^{2}=17.264, d f=1, p<0.05\right)$ and academic class $\left(X^{2}=15.499\right.$, $\mathrm{df}=5, \mathrm{p}<0.05)$. Caffeine use was significantly associated with academic class $\left(X^{2}=13.428, \quad d f=5, p<0.05\right)$. The use of inhalational solvents was significantly associated with age $\left(X^{2}=29.402, d f=18, p<0.05\right)$, gender $\left(X^{2}=6.598, d f=1, p<0.05\right)$ and academic class $\left(\mathrm{X}^{2}=21.505, \mathrm{df}=5, \mathrm{p}<0.05\right)$.

One hundred and ninety two subjects $(65.5 \%)$ used at least one of the psychoactive substances. This gives a prevalence rate of psychoactive substance use in this study as $65.5 \%$.

Table 1. Demographic and clinical characteristics of the respondents.

\begin{tabular}{lll}
\hline VARIABLE & FREQUENCY & $\mathbf{( \% )}$ \\
\hline Age (yrs) & & \\
$\leq 20$ & 18 & $(6.1)$ \\
$21-30$ & 262 & $(89.4)$ \\
$31-40$ & 12 & $(4.1)$ \\
$>40$ & 1 & $(0.3)$ \\
Mean age $=23.89 \pm 3.148 \mathrm{yrs}$ & & \\
Gender & & \\
Male & 166 & $(56.7)$ \\
Female & 127 & $(43.3)$ \\
Year of study & & \\
Year 1 & 32 & $(10.9)$ \\
2 & 46 & $(15.7)$ \\
\hline
\end{tabular}




\begin{tabular}{lll}
\hline VARIABLE & FREQUENCY & $\mathbf{( \% )}$ \\
\hline 3 & 44 & $(15.0)$ \\
4 & 85 & $(29.0)$ \\
5 & 73 & $(24.9)$ \\
6 & 12 & $(4.1)$ \\
Family history of use psychoactive substances & & \\
Positive family history & 54 & $(18.4)$ \\
Negative family history & 239 & $(81.6)$ \\
\hline
\end{tabular}

Table 2. Proportions of Rate of use of Psychoactive Substances.

\begin{tabular}{lll}
\hline PSYCHOACTIVE SUBSTANCES & YES (\%) & NO (\%) \\
\hline Alcohol & $178(60.8)$ & $115(39.2)$ \\
Cannabis & $112(38.2)$ & $181(61.8)$ \\
Cocaine & $113(38.6)$ & $180(61.4)$ \\
Heroine & $107(36.5)$ & $186(63.5)$ \\
Codeine & $141(48.1)$ & $152(51.9)$ \\
Other opiods & $91(31.1)$ & $202(68.9)$ \\
Sleeping pills & $129(44.0)$ & $164(56)$ \\
Nicotine & $128(43.7)$ & $165(56.3)$ \\
Caffeine & $168(57.3)$ & $125(42.7)$ \\
Inhalational agents & $75(25.6)$ & $218(74.4)$ \\
\hline
\end{tabular}

Table 3. Distribution of Proportions of Psychoactive Substances used among Males and Females.

\begin{tabular}{lllll}
\hline & Female & \multicolumn{3}{l}{ Male } \\
\hline Psychoactive substance & Yes(\%) & No(\%) & Yes (\%) & No (\%) \\
Alcohol & $78(26.6)$ & $49(16.7)$ & $100(34.1)$ & $66(22.5)$ \\
Cannabis & $37(12.6)$ & $90(30.7)$ & $75(25.6)$ & $91(31.1)$ \\
Cocaine & $24(8.2)$ & $103(35.2)$ & $89(30.4)$ & $77(26.3)$ \\
Heroine & $26(8.9)$ & $101(34.5)$ & $81(27.6)$ & $85(29.0)$ \\
Codeine in cough & $48(16.4)$ & $79(27.0)$ & $93(31.7)$ & $73(24.9)$ \\
symptoms & $18(6.1)$ & $109(37.2)$ & $73(24.9)$ & $93(31.7)$ \\
Other opioids & $44(15.0)$ & $83(28.3)$ & $84(28.7)$ & $82(28.0)$ \\
Sleeping pills & $38(13.0)$ & $89(30.4)$ & $90(30.7)$ & $76(25.9)$ \\
Nicotine & $68(23.2)$ & $59(20.1)$ & $100(34.1)$ & $66(22.5)$ \\
Caffeine & $23(7.8)$ & $104(35.5)$ & $52(17.7)$ & $114(38.9)$ \\
Inhalational solvents & & & & \\
e.g.petrol, glue, etc. & & &
\end{tabular}

Table 4. Associationbetween the use of psychoactive substances and socio-demographic variables.

\begin{tabular}{|c|c|c|c|c|c|c|c|c|c|c|}
\hline $\begin{array}{l}\text { Socio-demographic } \\
\text { variable }\end{array}$ & $\begin{array}{l}\text { Alcohol; } X^{2}, \\
\text { df(p value) }\end{array}$ & cannabis & Cocaine & Heroine & codeine & $\begin{array}{l}\text { Other } \\
\text { opioids }\end{array}$ & $\begin{array}{l}\text { Sleeping } \\
\text { pills }\end{array}$ & nicotine & caffine & $\begin{array}{l}\text { Inhalation } \\
\text { al agents }\end{array}$ \\
\hline Age & $12.172,18$ & $23.641,18$ & $21.250,18$ & $23.74,18$ & $16.817,18$ & $15.693,1$ & $65.875,36$ & $23.834,18$ & $16.717,18$ & $29.402,18$ \\
\hline Age & $(0.838)$ & $(0.167)$ & $(0.267)$ & $(0.164)$ & $(0.536)$ & $(0.614)$ & $(0.001)$ & $(0.161)$ & $(0.543)$ & $(0.044)$ \\
\hline Gender-male/female & $0.042,1$ & $7.846,1$ & $36.602,1$ & $24.897,1$ & $9.577,1$ & $29.847,1$ & $9.862,2$ & $17.264,1$ & $1.319,1$ & $6.598,1$ \\
\hline Gender-male/female & (0.904) & $(0.005)$ & $(0.000)$ & $(0.000)$ & $(0.002)$ & $(0.000)$ & $(0.007)$ & $(0.000)$ & $(0.284)$ & $(0.010)$ \\
\hline $\begin{array}{l}\text { Academic class- } \\
\text { yr } 1,2,3,4,5,6\end{array}$ & $\begin{array}{l}7.891,5 \\
(0.162)\end{array}$ & $\begin{array}{l}14.916,5 \\
(0.011)\end{array}$ & $\begin{array}{l}10.074,5 \\
(0.073)\end{array}$ & $\begin{array}{l}12.272,5 \\
(0.031)\end{array}$ & $\begin{array}{l}7.091,3(0 . \\
214)\end{array}$ & $\begin{array}{l}15.962,5 \\
(0.007)\end{array}$ & $\begin{array}{l}8.440,10 \\
(0.0586)\end{array}$ & $\begin{array}{l}15.499,5 \\
(0.008)\end{array}$ & $\begin{array}{l}13.428,5 \\
(0.002)\end{array}$ & $\begin{array}{l}21.505,5 \\
(0.001)\end{array}$ \\
\hline $\begin{array}{l}\text { Family history - } \\
\text { yes/no }\end{array}$ & $\begin{array}{l}3.654,1 \\
(0.064)\end{array}$ & $\begin{array}{l}1275,1 \\
(0.281)\end{array}$ & $\begin{array}{l}3.52,1 \\
(0.071)\end{array}$ & $\begin{array}{l}3.204,1 \\
(0.073)\end{array}$ & $\begin{array}{l}359,1 \\
(0.549)\end{array}$ & $\begin{array}{l}8.157,1 \\
(0.003)\end{array}$ & $\begin{array}{l}0.485,2 \\
(0.785)\end{array}$ & $\begin{array}{l}0.032,1 \\
(0.880)\end{array}$ & $\begin{array}{l}1.457,1 \\
(0.286)\end{array}$ & $\begin{array}{l}0.004,1 \\
(0.951)\end{array}$ \\
\hline
\end{tabular}

\section{Discussion}

The prevalence of psychoactive substance use in this study is $65.5 \%$. Varying results have been reported by several researchers ranging from $9.2 \%$ to $66 \%[13,14,1516,17]$. The different figures can be attributed to differences in research methodologies used by various researchers as well as variations in culture of the study populations.

This study also demonstrated that the odds for using psychoactive substances were highest with alcohol, caffeine, codeine (in cough syrups) and nicotine. Hence they are the drugs that are most likely to be abused by the students. This result is in consonance with findings from other studies [18, 19]. These gateway substances have very high prevalence rates and eventually usher the user to experiment and abuse other more dangerous ones such as cocaine and heroine [20].

This study shows that the male gender is significantly associated with use of cannabis, cocaine, other opioids, sleeping pills and inhalational solvents. This is in line with findings from other studies $[21,22,23]$. It is important to note that there is a pathway in the brain that is responsible for rewarding behaviour. Opioids activate the reward pathway in the ventral tegmental area and nucleus accumbens while nicotine and alcohol also activates this pathway, although sometimes indirectly e.g via the globus pallidus [24]. All the psychoactive drugs activate this pathway by increasing dopamine transmission, hence addiction is a disease of the brain [25].

Age is significantly associated with the use of sleeping pills, and inhalation of solvents while academic class is significantly associated with cannabis, cocaine, opioids, sleeping pills, nicotine and inhalations of organic solvents. The higher the academic class, the more vulnerable one seems to become with respect to using these substances. A number of factors including increasing academic stress and peer group influence may be explanatory.

Family history of substance abuse was only significantly associated with opioids. This is at variance with other studies which maintain that family history of substance abuse is also significantly associated with other substances apart from opioids [22, 23].

Even though the rates of use of all the psychoactive substances were correspondingly higher among the males than the female students, the trend and the statistics of the female subjects is a cause for concern especially for alcohol $26.6 \%$ and caffeine $23.2 \%$. When the rate of use of psychoactive substances takes an upward trend among mothers to be, it only points to a grave future for the future generation with possible increase in prevalence of substance use related disorders including foetal alcohol syndrome and all other types of abnormalities in the newborn. 


\section{Conclusion}

The rate of use of psychoactive substances among university students who represent the future of the nation is disturbing. The staggering cost to society and the impact on the fabric of society in the future can only be imagined. Therefore concerted effort to address this grim challenge is imperative.

\section{Limitations}

This is a cross sectional study which examined the use of psychoactive substances. Therefore the application of the findings of this study to the general population should be done with caution. More longitudinal studies are needed to explore the types and rates of specific substance use disorders among the younger generation.

\section{References}

[1] Odejide AO; "Status of Drug Use/Abuse in Africa a Review". International Journal, Mental Health and Addiction 2006; 4(2): 87-102.

[2] Chukwujekwu DC, Stanley HO, Chu JC, Frank-Briggs A. The Prevalence of Drug Abuse among Secondary School Students in Eleme, A Sub-Urban Area of Rivers State, Nigeria. Journal of child language and communication disorders in Nigeria 2008; 1(2): 32-42.

[3] Kaplan HI Sadock BJ. Substance Related Disorders. In synopsis of Psychiatry. $8^{\text {th }}$ Edn.,Williams and Wilkins (New York) 2003;375:455

[4] WHO, Atlas on Substances Use Resources for the Prevention and Treatment of Substances Use Disorders, WHO, Geneva, Switzerland 2010.

[5] Tsefaye G, Drese A, HambiaMT Substance Abuse and Associated Factors among University Students in Ethiopia: A Cross-Sectional Study. Journal of Addiction 2014, Articles ID 96983, 8 pages.http://dx.doi.or/10.155/2014/96983.

[6] Whitsell M, Bachand A, Peel J, Brown M Familiat, Social and Individual Factors Contributing to Risk for Adolescent Substance Use. Journal of Addiction 2013, article ID 579310, 9 pages http://dx.org/10.155/2013/579310

[7] StanleyPC, Odejide AO. Socio-Demographic and Forensic Characteristics of Alcohol Abusers in Jos, Nigeria. Nigeria Journal of Medicine 2002;11(3):113-117.

[8] Obot IS. The Measurement of Drinking Patterns and Alcohol Related Problems in Nigeria. Journal of Substance Abuse 2000; 12:169-181.

[9] Odejide AO, Ohaeri JU. Use and Abuse of Alcohol in Nigeria. An Overview.In: Proceedings of Regional Symposium on Use and Abuse of Alcohol, Babarone, Botswana 1988, 206-220.

[10] Ohaeri JU, Oduyela SO; Odejide OA, Dipe TM.Ikwuagwu PU, Zamani A. The History and Drinking Behaviour of the Nigerian Students Palm Wine Drinkers Club. Drugs; Education, Prevention and Policy 1996;3,171-183.
[11] Stanley PC (ed) Alcohol: A Silent Killer. Port Harcourt,University of Port Harcourt Press, 2003, 1-68.

[12] Brisbee, S, Ordinioha B, Dienye FG Intersection between Alcohol Abuse and Intermiate Partner's Violence in a Rural Ijaw Community in Bayelsa State, South-South Nigeria.Journal of Interpersonal Violence 2011. Doi.1177/088626051.

[13] Kanyoni JM, Gishoma D. Ndahindora V. Prevalence of Psychoactive Substance Use among Youth in Rwanda. BMC research notes 2015;8:190 Doi:10.1186/s/3104-015-11482-2

[14] Okoza J, Aluede O. Drug Abuse among Students of Ambrose Alli University, Ekpoma Nigeria. Eur J Soc. Sci 2009,85-93.

[15] Otieno AO, Ofulla A. Drug Abuse in Kisiumu town Western Kenya Africa J. Food Agr Nutr Dev. 2009; 9(3):846-858.

[16] Atwoli L, Mungla PA, Ndungu MN, Kinoti KC, Ogot EM. Prevalence of Substance Use among College Students in Eldoret, Western Kenya. BMC Psychiatry. 2011;11:1-9.

[17] Reddy SP, Panday S, swart D, Jinabhai CC., Amisun SL, James S. et al. The South African Youth Risk Behaviour Survey 2002. Cape Town. South AfricanMedical Research Council 2003.

[18] Abiodun OA, Adelekan MI, Ogunremi OO, Oni GA, Obayan AO. Pattern of substance use Amongst Secondary School Students in Illorin, Northern Nigeria. West Afr. J Med 1994; 13:91-97.

[19] Centres for Disease Control and Prevention. Surveillance Summaries Morb Mortal Wkly Rep. 2004; 53:55-2. Available from; http://www.cdc.gov/mmwr/pdf/ss5302pdf

[20] Sussman S, Skara S. Rodriguez Y Pokhrel P. Non-Drug Use and Drug Use-Specific Spirituality as one year Predictors of Drug Use among High Risk Youth. Substance Use Misuse 2006;41:1801-1816.

[21] Akamnnioo, Adoyanto E. Correlates of Psychoactive Substance Use among Nigeria Adolescents. Sahel Medical Journal 2015;18(4);192-199.

[22] Champion KE, Teeson M, Newton NC. Patterns and Correlates of New Psychoactive Substance Use in a Sample of Australian High School Students. Drug and Alcohol Review 2016; 35:338-344.

[23] Manyike PC, Chinawa JM, Chinawa AT, Herbert AO, Nwokocha ARC, Odutola IO. Correlates for Psychoactive Substance Use among Boarding Secondary School Adolescents in Enugu, South East, Nigeria. BMC Pediatr 2016;16:78

[24] D; Chiara G, Bassareo V. Reward System and Addiction: What Dopamine does and doesn't do. Current Opinion in Pharmacology; 2007; 7(1): 69-76.

[25] Koob GF. Plasticity of Reward Neuro-circuitry and the Dark Side of Drug Addiction. Nature Neuroscience 2005;8:14421444 . 